\title{
Leukotriene $D_{4}$ induces gene expression in human monocytes through cysteinyl leukotriene type I receptor
}

\author{
Grzegorz Woszczek, MD, PhDa, Li-Yuan Chen, PhD ${ }^{\mathrm{a}}$, Sahrudaya Nagineni, MS ${ }^{\mathrm{a}}$, Steven \\ Kern, BS ${ }^{a}$, Jennifer Barb, MS ${ }^{b}$, Peter J. Munson, PhD $^{b}$, Carolea Logun, MS ${ }^{a}$, Robert L. \\ Danner, MD $^{\mathrm{a}}$, and James H. Shelhamer, $\mathbf{M D}^{\mathrm{a}}$ \\ aThe Critical Care Medicine Department, Clinical Center, National Institutes of Health \\ ${ }^{b}$ The Mathematical and Statistical Computing Laboratory, Center for Information Technology, \\ National Institutes of Health
}

\section{Abstract}

Background-Cysteinyl leukotrienes (CysLTs) are important mediators of innate immune responsiveness and chronic inflammatory diseases. CysLTs acting through CysLT receptors can influence the migration and activity of cells, such as eosinophils, monocytes, and dendritic cells.

Objective-We sought to determine the gene expression signature of human monocytes in response to CysLTs and to elucidate the signaling pathways involved in monocyte activation.

Methods-Gene expression was analyzed by using oligonucleotide microarrays. Responsiveness to CysLTs was assessed by using real-time PCR, calcium flux, kinase activation, and chemotaxis assays.

Results-CysLT type 1 receptor $\left(\right.$ CysLTR $\left._{1}\right)$ transcript 1 is predominantly expressed in human monocytes, and CysLTs signal through CysLTR ${ }_{1}$ in these cells. Several immediate-early genes, including early growth response 2 and 3, FBJ murine osteosarcoma viral oncogene homolog B, activating transcription factor 3 , and nuclear receptor subfamily 4 were significantly induced by leukotriene (LT) $\mathrm{D}_{4}$. This effect was mediated by CysLTR 1 coupled to the $\mathrm{G}$ protein a inhibitory subunit, activation of phospholipase $\mathrm{C}$, and inositol-1,4,5-triphosphate and store-operated calcium channels. $\mathrm{LTD}_{4}$ induced $\mathrm{p} 38$ mitogen-activated protein kinase phosphorylation, a pathway also involved in the regulation of immediate-early gene expression in monocytes. $\mathrm{LTD}_{4}$ stimulated monocyte chemotactic activity that was fully blocked by a selective CysLTR ${ }_{1}$ inhibitor, MK571, and pertussis toxin, suggesting that $\mathrm{CysLTR}_{1}$ coupled to the $\mathrm{G}$ protein a inhibitory subunit is a dominant functional pathway in human monocytes.

Conclusion-Our data show that CysLTs acting through CysLTR 1 can significantly influence the activation and migration of human monocytes and that these effects can be fully inhibited by CysLTR $_{1}$ antagonists.

Reprint requests: James H. Shelhamer, MD, Critical Care Medicine Department, Clinical Center, National Institutes of Health, Bldg 10 Rm 2C145, 9000 Rockville Pike, Bethesda, MD 20892. jshelhamer@cc.nih.gov.

Disclosure of potential conflict of interest: The authors have declared that they have no conflict of interest. 


\section{Keywords}

Human monocytes; cysteinyl leukotrienes; immediate-early genes; chemotaxis

Circulating monocytes have long been recognized as a heterogeneous population that gives rise to macrophages, dendritic cells, osteoclasts, and endothelial cell progenitors. ${ }^{1,2}$ Monocytes, once released from bone marrow, are only transiently present in the circulation because they disperse to different tissues to complete their differentiation into these disparate cell types. Monocytes have been mainly viewed as a pool of precursor cells for tissue macrophages and dendritic cells that do not participate directly in immune responsiveness. However, a recent study in mice demonstrated that monocytes can process antigen in the bone marrow and effectively present it later in lymph nodes, suggesting their direct involvement in the immune response to antigens. ${ }^{3}$

Cysteinyl leukotrienes (CysLTs; leukotriene [LT] $\mathrm{C}_{4}, \mathrm{LTD}_{4}$, and $\mathrm{LTE}_{4}$ ) are lipid mediators derived from arachidonic acid through the 5-lipoxygenase pathway that are involved in pathogenesis of a variety of chronic inflammatory disorders, including bronchial asthma, allergic rhinitis, pulmonary fibrosis, and atherosclerosis. ${ }^{4,5}$ The biologic actionsof CysLTs can be mediated through3 known $\mathrm{G}$ protein-coupled receptors: the CysLT type 1 $\left(\text { CysLTR }_{1}\right)^{6}$ and type $2\left(\text { CysLTR }_{2}\right)^{7}$ receptors and the recently described receptor GPR $17 .^{8}$ CysLTs have been recognized primarily as mediators involved in the development of phenotypes characteristic for bronchial asthma, such as bronchoconstriction, mucus secretion, and bronchial hyperresponsiveness. ${ }^{9}$ They are also believed to play an important role in cell trafficking and innate immune responses. CysLTs are potent chemoattractants for eosinophils ${ }^{10}$ and $\mathrm{CD} 34^{+}$hematopoetic progenitor cells. ${ }^{11}$ CysLTs also promote migration of monocyte-derived dendritic cells in response to CCL19. ${ }^{12}$ It has been shown in a murine model of pulmonary inflammation that CysLTs were required not only for antigen-induced eosinophil infiltration, goblet cell hyperplasia, and mucus hypersecretion but also for an initiation and amplification of antigen-specific $\mathrm{T}_{\mathrm{H}}$ 2-dependent inflammatory responses. ${ }^{13}$ These effects suggest an important role for CysLTs in the regulation of adaptive immune responses, probably through dendritic cells. Interestingly, it has been shown that monocytederived dendritic cells require for differentiation multidrug resistance protein 1 (ABCC1) transporter activity, which actively transports $\mathrm{LTC}_{4}$ out of the cell. ${ }^{14}$ Similarly, the activity of both ABCC1 and CysLTs was crucial for CCL19-induced migration of dendritic cells to lymph nodes in vivo in a murine model. ${ }^{15} \mathrm{In}$ asthmatic patients peripheral blood dendritic cells migrate into the bronchial mucosa during allergic inflammation, ${ }^{16}$ and pretreatment with the antileukotriene drug pranlukast significantly attenuates allergen-induced airways responses and alters circulating dendritic cells. ${ }^{17}$ Altogether, it seems plausible that CysLTs can play a significant role in monocyte and monocyte-derived dendritic cell migration and differentiation and thereby participate in key aspects of the immune response.

However, very little is known about CysLT-induced effects and signaling in monocytes, especially human monocytes. mRNA of both CysLTR 1 and CysLTR 2 has been detected in human monocytes, and it was reported that $\mathrm{LTD}_{4}$ can induce intracellular calcium flux and chemotactic activity through CysLTR ${ }_{1}$ in peripheral blood monocytes. ${ }^{12,18}$ Nonetheless, the 
signal transduction pathways used by CysLTR 1 and other CysLT receptors, as well as the precise role in the immune response of human monocytes, has not been fully addressed. Here we examined the gene signature response of human monocytes exposed to CysLTs and elucidated the signaling pathways involved in monocyte activation in relation to the expression of CysLT receptors.

\section{METHODS}

\section{Materials}

$\mathrm{LTC}_{4}, \mathrm{LTD}_{4}, \mathrm{LTE}_{4}$, and MK571 (Cayman Chemical, Ann Arbor, Mich); pertussis toxin (Biomol, Plymouth Meeting, Pa); 2APB, U73122, SB203580, SB202190, PD98059, U0126, ethyleneglycolbis-( $\beta$-aminoethylether)-N,N, $\mathrm{N}^{\prime}, \mathrm{N}^{\prime}$-tetraacetic acid (EGTA), and BAPTA/AM (EMD Biosciences, San Diego, Calif); anti-phospho-p38 mitogen-activated protein kinase (MAPK), anti-phospho-p44/42 MAPK, anti-p38 MAPK, and anti-p44/42 MAPK antibodies (Cell Signaling, Danvers, Mass); anti- $\beta$ actin antibody (Sigma-Aldrich, St Louis, Mo); and peroxidase-conjugated anti-rabbit antibodies (Jackson Immunoresearch, West Grove, $\mathrm{Pa}$ ) were obtained from the manufacturers.

\section{Cell culture}

Human elutriated monocytes from healthy donors were obtained by using an institutional review board-approved protocol from the National Institutes of Health Blood Bank (Bethesda, Md), resuspended in RPMI 1640 medium supplemented with 10\% heatinactivated FBS (Invitrogen, Carlsbad, Calif), and $2 \mathrm{mmol} / \mathrm{L} \mathrm{L}$-glutamine (Invitrogen) and allowed to rest overnight before experiments. More than $95 \%$ of cells were CD14 ${ }^{+}$, as determined by means of flow cytometry with fluorescein isothiocyanate-labeled anti-human CD14 (BD Biosciences, San Jose, Calif) with a FACScan flow cytometer (BD Biosciences). Human embryonic kidney (HEK293) cells (ATCC, Manassas, Va) were cultured in Dulbecco's modified Eagle's medium (Invitrogen) supplemented with 10\% FBS.

\section{Microarray analysis}

Microarray gene expression was performed on total RNA extracted from monocytes by using Affymetrix HG U133 plus 2.0 arrays, according to the manufacturer's protocols (Affymetrix, Santa Clara, Calif), and described in detail in the Methods section of the Online Repository at www.jacionline.org. Raw and processed data were submitted to National Center for Biotechnology Information Gene Expression Omnibus database (accession no. GSE7807).

\section{Real-time PCR}

The methods for real-time TaqMan PCR assay and primers and probes sequences are described in the Methods section of this article's Online Repository at www.jacionline.org.

\section{Calcium mobilization assay}

Calcium mobilization experiments were conducted with a FLIPR Calcium 3 assay kit (Molecular Devices, Sunnyvale, Calif), according to the manufacturer's instructions. 
Monocytes $\left(2 \times 10^{5}\right.$ cells per well) were plated into poly-L-lysine-coated 96-well plates and incubated in RPMI 1640 supplemented with $10 \mathrm{mmol} / \mathrm{L}$ HEPES and FLIPR 3 assay reagent. After incubation for 1 hour at $37^{\circ} \mathrm{C}$, fluorescence was measured every 4 seconds by using the FlexStation (Molecular Devices).

HEK293 cells were grown in 75- $\mathrm{cm}^{2}$ flasks and transfected with empty pcDNA 3.1 vector or CysLTR $_{1}$ or CysLTR 2 expression vectors (UMR cDNA Resource Center, Rolla, Mo) by using Lipofectamine 2000 (Invitrogen) in serum free medium (Opti-MEM I, Invitrogen), transferred to poly-L-lysine-coated 96-well plates after 24 hours, and used for calcium mobilization experiments after another 24 hours of incubation.

\section{Immunoblotting}

The methods for immunoblotting are described in the Methods section of this article's Online Repository at www.jacionline.org.

\section{Chemotaxis assay}

Chemotaxis experiments were performed by using a modified Boyden chamber (Neuro Probe, Gaithersburg, Md). Elutriated monocytes were washed and resuspended in RPMI supplemented with $10 \mathrm{mmol} / \mathrm{L}$ HEPES, $2 \mathrm{mmol} / \mathrm{L}$ L-glutamine, and $1 \%$ BSA (Sigma). Chemoattractants were resuspended in the same medium and added to the lower wells. Controls wells received medium without chemoattractant. Monocytes $\left(7.5 \times 10^{4}\right)$ were added to the upper wells and separated by using a polycarbonate filter with 5 - $\mu \mathrm{m}$ pores (Neuro Probe). The number of cells that migrated to the lower surface of the filter was counted after 2 hours' incubation.

\section{Statistical analysis}

Data were analyzed by means of 1-way ANOVA or paired and unpaired Student $t$ tests, as appropriate. Differences were considered significant at a $P$ value of less than .05 .

\section{RESULTS}

\section{$\mathrm{LTD}_{4}$ induces gene expression in human monocytes}

Elutriated monocytes from 4 healthy donors were stimulated with $100 \mathrm{nmol} / \mathrm{L} \mathrm{LTD}_{4}$ for 30 minutes and analyzed with microarrays to determine whether CysLTs induce gene expression in human monocytes. Because of variability in response to $\mathrm{LTD}_{4}$ among studied donors, a 2-fold increase in expression observed in at least 3 of 4 donors was used to identify regulated genes. $\mathrm{LTD}_{4}$ induced 7 genes belonging to families of transcription factors and signaling molecules at 30 minutes (Table I). The expression of 5 identified genes was studied by using real-time PCR in 3 additional donors to verify the microarray results (Table I). As expected, the expression of all studied genes was upregulated by $\mathrm{LTD}_{4}$ stimulation, with higher changes observed in real-time PCR than in microarray experiments. The 2 most highly upregulated genes were analyzed for transcript kinetics by using real-time PCR to further verify the pattern of gene upregulation induced by $\mathrm{LTD}_{4}$. $\mathrm{LTD}_{4}$ induced a significant increase in the mRNA levels of FBJ murine osteosarcoma viral oncogene homolog B 
(FOSB) and Egr2 in a time-dependent fashion, with the highest increase observed between 30 and 60 minutes and returning to baseline after 2 hours (Fig 1).

\section{Human monocytes express mainly CysLTR 1 transcript 1}

The steady-state levels of mRNA for 3 known CysLT receptors were measured in elutriated monocytes to define receptors responsible for $\mathrm{LTD}_{4}$-induced gene expression. In addition, the expression of 2 known alternatively spliced transcripts for CysLTR 1 was analyzed. CysLTR $_{1}$ mRNA (mean cycle, $26.84 \pm 0.11$ ) was the most highly expressed, followed by 16fold lower levels of CysLTR 2 mRNA (mean cycle, $30.78 \pm 0.12$ ), with nondetectable levels of mRNA for GPR17. Both alternative splice variants for CysLTR 1 were found in

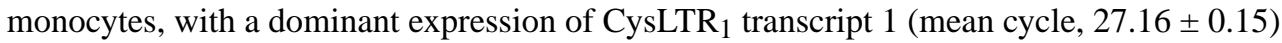
and more than 40-fold lower expression of CysLTR 1 transcript 2 (mean cycle, $32.64 \pm 0.26$ ). Because both alternative CysLTR 1 transcripts encode the same protein, CysLTR ${ }_{1}$ seems to be the dominant CysLT receptor expressed in human monocytes, as determined by means of mRNA analysis.

\section{CysLT-induced calcium flux in monocytes resembles CysLTR $_{1}$ activation}

CysLTs acting through their receptors induce intracellular calcium flux in monocytes. Elutriated monocytes were stimulated with different concentrations of $\mathrm{LTC}_{4}, \mathrm{LTD}_{4}$, and $\mathrm{LTE}_{4}$, and intracellular calcium responses were measured to define the pattern of calcium signaling in response to CysLTs (Fig 2, $A$ ). All 3 CysLTs induced calcium mobilization, with $\mathrm{LTD}_{4}$ showing the highest potency, followed by $\mathrm{LTC}_{4}$ and $\mathrm{LTE}_{4}$. Because the pattern of calcium mobilization induced by CysLTs resembled signaling characteristic for CysLTR 1 only $\left(\mathrm{LTD}_{4}>\mathrm{LTC}_{4}>\mathrm{LTE}_{4}\right)$, calcium flux was also measured in HEK293 cells transiently transfected with a human CysLTR 1 expression construct for comparison (Fig 2, B). HEK293 cells transfected with empty vector did not respond to leukotrienes. CysLTR ${ }_{1}$-transfected HEK293 cells showed a pattern of calcium mobilization $\left(\mathrm{LTD}_{4}>\mathrm{LTC}_{4}>\mathrm{LTE}_{4}\right)$ similar to the pattern observed in human monocytes. HEK293 cells transfected with human CysLTR 2 expression construct showed equal potency of $\mathrm{LTD}_{4}$ - and $\mathrm{LTC}_{4}$-induced calcium flux (data not shown).

\section{LTD $_{4}$ induces calcium flux through $G$ protein a inhibitory subunit-coupled CysLTR $\mathbf{R}_{1}$ in monocytes}

To fully characterize CysLT-induced intracellular calcium mobilization in monocytes, elutriated monocytes were preincubated with the CysLTR ${ }_{1}$ antagonist MK571 $(100 \mathrm{nmol} / \mathrm{L})$ for 10 minutes, with the $\mathrm{G}$ protein a inhibitory subunit $\left(\mathrm{Ga}_{\mathrm{i} / \mathrm{o}}\right)$ inhibitor pertussis toxin $(100$ $\mathrm{ng} / \mathrm{mL}$ ) overnight, with the inositol-1,4,5-triphosphate $\left(\mathrm{IP}_{3}\right)$ receptor inhibitor 2APB (50 $\mu \mathrm{mol} / \mathrm{L})$ for 10 minutes, with the phospholipase C inhibitor U73122 $(2 \mu \mathrm{mol} / \mathrm{L})$ for 10 minutes, with the extracellular calcium-chelating agent EGTA $(5 \mathrm{mmol} / \mathrm{L})$ for 30 minutes, with the intracellular calcium-chelating agent BAPTA/AM $(30 \mu \mathrm{mol} / \mathrm{L})$ for 30 minutes, with thapsigargin $(1 \mu \mathrm{mol} / \mathrm{L})$ for 30 minutes to deplete endoplasmic reticular calcium stores, or with the plasma membrane channels inhibitor (L-type) verapamil $(25 \mu \mathrm{mol} / \mathrm{L})$ for 30 minutes and then stimulated with $\mathrm{LTD}_{4}(100 \mathrm{nmol} / \mathrm{L}$; Fig 3). Calcium mobilization was fully inhibited by preincubation with MK571, pertussis toxin, 2APB, and U73122, suggesting that calcium flux was induced by CysLTR 1 coupled to $\mathrm{Ga}_{\mathrm{i} / \mathrm{o}}$, followed by activation of 
phospholipase $\mathrm{C}$ and $\mathrm{IP}_{3}$ signaling. Interestingly, both extracellular and intracellular calcium were required for $\mathrm{LTD}_{4}$-induced signaling because EGTA and BAPTA/AM preincubation inhibited calcium mobilization. Because calcium mobilization was inhibited also by means of pre-incubation with thapsigargin, but not with verapamil, these data point to storeoperated calcium-channel activation by $\mathrm{LTD}_{4}$ stimulation.

\section{LTD $_{4}$ activates p38 MAPK in monocytes}

To analyze whether CysLTs can activate MAPK pathways in monocytes, cells were incubated overnight in medium with a reduced amount of FBS (RPMI 1640 plus 2\% FBS) and stimulated with $\operatorname{LTD}_{4}(100 \mathrm{nmol} / \mathrm{L})$, and the phosphorylation of $\mathrm{p} 44 / 42$ and $\mathrm{p} 38$ MAPKs was measured (Fig 4, $A$ ). LTD $_{4}$ induced phosphorylation of p38 MAPK in a timedependent fashion, with maximum effect observed after 10 minutes, but it did not induce detectable p44/42 kinase phosphorylation. LTD $_{4}$ induction of $\mathrm{p} 38$ phosphorylation acted through CysLTR 1 , an effect fully inhibited by preincubation with MK571 (Fig 4, B).

\section{LTD $_{4}$-induced gene expression requires CysLTR $_{1}$-mediated calcium release and MAPK activation}

To further characterize $\mathrm{LTD}_{4}$-induced gene expression, elutriated monocytes were preincubated with MK571 (100 nmol/L for 10 minutes), pertussis toxin $(100 \mathrm{ng} / \mathrm{mL}$ overnight), 2APB ( $50 \mu \mathrm{mol} / \mathrm{L}$ for 10 minutes), the p38 MAPK inhibitor SB203580 (5 $\mu \mathrm{mol} / \mathrm{L}$ for 30 minutes), the $\mathrm{p} 44 / 42$ MAPK inhibitor PD98059 (10 $\mu \mathrm{mol} / \mathrm{L}$ for 30 minutes), and the intracellular calcium-chelating agent BAPTA/AM (30 $\mu \mathrm{mol} / \mathrm{L}$ for 30 minutes), followed by stimulation with $\mathrm{LTD}_{4}$ for 30 minutes. All tested inhibitors significantly inhibited $\mathrm{LTD}_{4}$-induced gene expression (Fig 5, $A$ and $B$ ). In addition, other p38 (SB202190) and p44/42 (U0126) MAPK pathway inhibitors also inhibited EGR2 and FOSB expression in a concentration-dependent fashion (Fig 5, $C$ and $D$ ). Similarly, NR4A2, activating transcription factor 3, and Egr3 gene expression was inhibited by p38, p44/ 42, and calcium flux inhibitors (data not shown). These data suggest that in human monocytes $\mathrm{LTD}_{4}$ activates CysLTR 1 coupled to $\mathrm{Ga}_{\mathrm{i} / \mathrm{o}}$, which subsequently signals through calcium release and MAPK pathways to regulate gene expression.

\section{LTD $_{4}$ induces chemotaxis of monocytes through $\mathrm{Ga}_{\mathrm{i} / \mathrm{o}}$-coupled CysLTR}

Human elutriated monocytes showed a significant concentration-dependent chemotactic activity in response to $\mathrm{LTD}_{4}$ (Fig 6, $A$ ). Migration was fully inhibited by pretreatment of cells with MK571 and pertussis toxin and partially by pretreatment with p38 inhibitors (SB203580 and SB202190) and p44/42 pathway inhibitors (PD98059 and U0126; Fig 6, B), suggesting that CysLTR 1 coupled to $\mathrm{Ga}_{\mathrm{i} / \mathrm{o}}$ and MAPK signaling were essential for chemotaxis in response to $\mathrm{LTD}_{4}$.

\section{DISCUSSION}

CysLTs are proinflammatory mediators that play an important role in the pathogenesis of allergic diseases. The role of monocytes in allergy and allergic diseases is not well understood. Monocytes are a heterogeneous population of cells that, after activation and differentiation, can participate in many pathways of innate and adaptive immune 
responsiveness. We have shown here that CysLTs can directly influence the activation and function of human monocytes. $\mathrm{LTD}_{4}$ activates monocyte expression of immediate-early genes. The expression of mRNA for transcriptional regulators, such as FOSB, EGR2, EGR3, NR4A2, and TSC22D3, was quickly induced. Expression of EGR2 and FOSB reached a maximum between 30 and 60 minutes. A 30-minute time point was selected for the microarray study to detect genes that were directly regulated by $\mathrm{LTD}_{4}$ and by this to define a gene signature that could be specific for CysLT signaling. To our knowledge, this is the first study analyzing the gene expression profile pattern associated with CysLTR $_{1}$ signaling in human primary cells.

The only other comparable microarray data come from a study using human umbilical vein endothelial cells (HUVECs), ${ }^{19}$ in which 37 genes were induced after 60 minutes of stimulation with $\mathrm{LTD}_{4}$. Notably, the same families of transcription factors up-regulated in our study (EGR, activating transcription factor, and NR) were also induced by $\mathrm{LTD}_{4}$ in endothelial cells. HUVECs express only CysLTR 2 , coupled to $\mathrm{Ga}_{\mathrm{q} / 11}$, and thus the $\mathrm{LTD}_{4}$ induced gene signature observed in these cells can be assigned to CysLTR 2 signaling. In contrast, our data suggest that human monocytes signal mainly through CysLTR 1 coupled to $\mathrm{Ga}_{\mathrm{i} / \mathrm{o}}$ in response to $\mathrm{LTD}_{4}$ stimulation. These data suggest that apart from differences in coupling to different $\mathrm{G}$ proteins by CysLTR ${ }_{1}$ and $\mathrm{CysLTR}_{2}$, both receptors can induce the early expression of similar transcription factors. However, there were also some differences in gene signatures induced by both receptors. In monocytes we observed an induction of FOSB and TSC22D3, transcription factors that were not upregulated in HUVECs. In addition, EGR1, a gene potently induced by CysLTR 2 signaling, was not changed in our study. These differences could be a result of signaling in different cell types, but they also could reflect the existence of divergent pathways that are used by CysLTR ${ }_{1}$ and CysLTR 2 .

Several genes induced by $\mathrm{LTD}_{4}$ in monocytes in our study have been shown to be involved in the regulation of inflammatory processes. Interestingly, Egr genes seem to play an important role in monocytic differentiation and activation, ${ }^{20}$ suggesting that CysLT stimulation might potentially influence monocyte functions in vivo. FOSB is a member of the Fos family (c-Fos, FOSB, Fra-1, and Fra-2), which combines with Jun family members (c-Jun, JunB, and Jun D) to form activator protein 1, a transcription factor with very potent proinflammatory effects. In a recent study Thompson et $\mathrm{al}^{21}$ showed that in HEK293 cells stably transfected with CysLTR 1 , stimulation with LTD $_{4}$ induced IL-8 gene expression through activation of c-Jun/c-Fos complex and nuclear factor (NF) $\kappa B$. However, we did not see any changes in the mRNA expression of genes related to NF- $\mathrm{kB}$ and c-Jun/c-Fos in human monocytes. This could underline the importance of studying CysLT signaling in primary human cells because artificially created models might demonstrate different signaling capacities. Another possibility exists that transcription factors induced by CysLTs might regulate gene expression indirectly through inter-actions with other transcription factors or that $\mathrm{LTD}_{4}$ might induce posttranslational modifications. This type of relationship was demonstrated in the case of EGR proteins, which, by means of interaction with NF- $\mathrm{kB}$ p50 and p65, control transcription of genes encoding inflammatory cytokines. ${ }^{22}$

According to our data, CysLTR 1 seems to be the dominant CysLT receptor present in human monocytes. We previously showed that in human PBMCs 2 alternative splice variants of 
CysLTR $_{1}$ can be detected. ${ }^{23}$ Analysis of mRNA expression showed that CysLTR transcript 1 is the major transcript detected in monocytes, with 20- to 40-fold higher levels than CysLTR $_{1}$ transcript 2 and CysLTR 2 . Also, functional data point to CysLTR ${ }_{1}$ signaling as the major pathway in response to CysLTs because calcium signaling, gene expression, activation of $\mathrm{p} 38$ MAPK, and monocyte chemotaxis all were inhibited by the selective CysLTR $_{1}$ inhibitor MK571. In addition, the same potency of CysLT calcium signaling $\left(\mathrm{LTD}_{4}>\mathrm{LTC}_{4}\right.$ $>\mathrm{LTE}_{4}$ ) in monocytes and in CysLTR ${ }_{1}$-transfected HEK293 cells strongly suggests that only CysLTR $_{1}$ is functional in human monocytes. In HU-VECs and in artificial systems, CysLTR $_{2}$ has been shown to couple to $\mathrm{Ga}_{\mathrm{q} / 11}$ and subsequently signal through phospholipase $\mathrm{C}$ and calcium mobilization. ${ }^{7,24}$ Because the effects induced by CysLTs in monocytes were inhibited by MK571, as well as by pertussis toxin $\left(\mathrm{Ga}_{\mathrm{i} / \mathrm{o}}\right.$ signaling inhibitor), it is rather improbable that CysLTR $_{2}$ is functional in these cells.

In this study we provide evidence that in human monocytes $\mathrm{LTD}_{4}$ stimulates CysLTR 1 coupled to pertussis toxin-sensitive $\mathrm{Ga}_{\mathrm{i} / \mathrm{o}}$, causing intracellular calcium mobilization, gene expression, and chemotaxis. The range of specific inhibitors used allows us to define this pathway as follows: stimulation of CysLTR ${ }_{1}$ by $\mathrm{LTD}_{4}$ activates $\mathrm{Ga}_{\mathrm{i} / \mathrm{o}}$, which then activates phospholipase $\mathrm{C}$ and $\mathrm{IP}_{3}$ generation and leads to activation of store-operated calcium channels. Both intracellular and extracellular calcium ions are required to activate gene transcription. In addition, $\mathrm{LTD}_{4}$ stimulation activates the $\mathrm{p} 38$ and probably the $\mathrm{p} 44 / 42$ MAPK pathways, which also are required for gene expression regulation. However, we were unable to detect $\mathrm{p} 44 / 42$ phosphorylation in $\mathrm{LTD}_{4}$-stimulated monocytes. It is possible that p44/42 is weakly phosphorylated by $\mathrm{LTD}_{4}$ in monocytes at a level not detectable by using standard methods, that $\mathrm{p} 44 / 42$ is phosphorylated at a different time point, or that $\mathrm{LTD}_{4}$ activates other pathways than p38 and p44/42 MAPK. Interestingly, it has been suggested that both PD98059 and U0126, apart from inhibiting the p44/42 pathway, can inhibit extracellular signal-regulated kinase (ERK) 5 MAPK at micromolar concentrations. ${ }^{25}$

The CysLTR ${ }_{1}$ signaling pathway defined here differs in comparison to that described by others in THP-1 and U937 monocytic cell lines. ${ }^{26,27}$ In THP-1 cells it has been shown that $\mathrm{LTD}_{4}$ has at least 2 distinct signaling pathways: a pertussis toxin-insensitive ERK kinase activation through protein kinase $\mathrm{C}$ and a pertussis toxin-sensitive chemotactic response. In U937 cells LTD $_{4}$ activation of CysLTR 1 leads to Ras activation and ERK phosphorylation, primarily through signal transduction events that are dependent on pertussis toxin-sensitive $\mathrm{Ga}_{\mathrm{i} / \mathrm{o}}$ protein, phospholipase $\mathrm{C}$, and calcium. However, calcium signaling was only partially inhibited by pertussis toxin, suggesting simultaneous coupling to other $\mathrm{G}$ proteins. The important issue raised by our study is that none of the described cell lines reproduces $\mathrm{LTD}_{4}$ signaling events found in primary monocytes. Thus the results regarding CysLT signaling obtained from monocytic cell lines and recombinant models should be verified in primary cells before further conclusions can be made. Interestingly, in cultured human mast cells, it was shown that CysLTR 1 signals through a pertussis toxin-insensitive $\mathrm{Ga}_{\mathrm{q} / 11}$ pathway to ERK phosphorylation. ${ }^{28}$ Collectively, these data show a very complex picture of CysLT signaling pathways that is dependent on cell type, model used, and phenotype analyzed.

In conclusion, we have demonstrated that $\mathrm{LTD}_{4}$ acting through CysLTR ${ }_{1}$ coupled to $\mathrm{Ga}_{\mathrm{i} / \mathrm{o}}$ activates in human monocytes immediate-early gene expression, p38 MAPK 
phosphorylation, and chemotactic responses. Because CysLT antagonists can significantly influence allergen-induced airway responses ${ }^{29,30}$ and dendritic cell migration ${ }^{17}$ in asthmatic subjects, it might be hypothesized that some of the anti-inflammatory effects of currently used CysLT antagonists are related to the inhibition of CysLT-induced monocyte and peripheral blood dendritic cell activation, differentiation, and migration.

\section{METHODS}

\section{Microarray analysis}

Total RNAwas extracted from elutriated monocytes by using QIA Shredder columns and an RNeasy mini kit, treated with DNase (Qiagen, Valencia, Calif), and quantitated with a NanoDrop spectrophotometer (BioLabNet, Great Falls, Va). RNA quality was assessed by using a 1.2\% agarose formaldehyde gel containing Sybr Green II (Molecular Probes, Eugene, Ore), visualizing $18 \mathrm{~S}$ and $28 \mathrm{~S}$ ribosomal RNA bands.

cDNA was prepared according to Affymetrix methods, cleaned, and used for the subsequent in vitro transcription reaction to prepare biotin-labeled complementary RNA. The cRNA was cleaned, fragmented, and hybridized to Affymetrix HG U133 plus 2.0 arrays, which were scanned with an Affymetrix 3000 scanner (Affymetrix, Santa Clara, Calif). Gene expression was quantitated with GCOS 1.4. The results obtained were transferred to a central database for storage and processing (National Institutes of Health LIMS and GCOS Server, Affymetrix). Raw data and processed data were also submitted to the National Center for Biotechnology Information Gene Expression Omnibus database (accession no. GSE7807). Affymetrix signal values from the GCOS 1.4 software were normalized with an adaptive variance-stabilizing, quantile-normalizing transformation (P. J. Munson, GeneLogic Workshop of Low Level Analysis of Affymetrix GeneChip Data, 2001, software available at http://abs.cit.nih.gov/geneexpression.html). The transform, termed S10, is scaled to match the logarithm transform (base 10).

\section{Real-time PCR}

Total RNAwas extracted from monocytes as above, and mRNA expression for selected genes was measured by using real-time PCR performed on an ABI Prism 7900 sequence detection system (Applied Biosystems, Foster City, Calif) with the following commercially available probe and primers sets (Applied Biosystems):CysLTR 1 ,Hs00272624_s1;CysLTR 2 ,Hs00252658_s1;GPR17,Hs00171137_m1; FOSB, Hs00171851_m1; EGR2, Hs00166165_m1; EGR3, Hs00231780_m1; NR4A2, Hs00428691_m1; and activating transcription factor 3, Hs00231069. For CysLTR 1 transcript-specific mRNA expression, the following primers and probes were used: $\mathrm{CysLTR}_{1}$ transcript 1, 5'AACGCAAAAGGACAGTAAACTGTG, 5'ATCAATGCCTTTTACGGTGTAATATTAG, probe 5'CCTTGAAGTTAGCAGCGTGGGCTTCC; CysLTR 1 transcript 2, 5' AACGCAAAAGGACAGTAAACTGTG, 5'CTGTTTCATCCATGTTTCTCTACGA, probe 5'C CTTGAAGTTAGCAGGCACAAAGCAGACA. 
Reverse transcription and PCR were performed with an RT kit and TaqMan Universal PCR master mix (Applied Biosystems), according to the manufacturer's directions. Relative gene expression was normalized to glyceralde-hyde-3-phosphate dehydrogenase transcripts and calculated as a fold change compared with control values.

\section{Immunoblotting}

Cells were collected into a buffer containing $50 \mathrm{mmol} / \mathrm{L}$ HEPES, $0.25 \%$ Triton X-100, and Complete Mini protease inhibitor cocktail (Roche, Nutley, NJ) and sonicated. Proteins (30 $\mu \mathrm{g}$ ) were separated on $10 \%$ SDS Tris-glycine gel (Invitrogen), transferred to membranes, blocked with ECL Advance blocking agent (Amersham Biosciences, Pittsburg, Pa), and incubated with primary antibodies overnight at $4^{\circ} \mathrm{C}(1: 1000$ dilution), followed by the appropriate peroxidase-conjugated secondary antibodies for 1 hour at room temperature. The membranes were developed by using an ECL Advance Western Blotting Detection kit (Amersham Biosciences) and analyzed with the Image Station 440 (Eastman Kodak, Rochester, NY). For control $\beta$ actin, antibodies were stripped from membranes with Blot Fresh Stripping Reagent (SignaGen Laboratories, Gaithersburg, Md) and developed as above.

\section{Abbreviations used}

CysLT Cysteinyl leukotriene

CysLTR $_{1}$ Cysteinyl leukotriene type 1 receptor

CysLTR2 $_{2}$ Cysteinyl leukotriene type 2 receptor

EGR Early growth response

EGTA Ethyleneglycol-bis-( $\beta$-aminoethylether)-N,N, $\mathrm{N}^{\prime}, \mathrm{N}^{\prime}$-tetraacetic acid

ERK Extracellular signal-regulated kinase

FOSB FBJ murine osteosarcoma viral oncogene homolog B

$\mathbf{G a}_{\mathbf{i} / \mathbf{0}} \quad \mathrm{G}$ protein a inhibitory subunit

HUVEC Human umbilical vein endothelial cell

$\mathbf{I P}_{3} \quad$ Inositol-1,4,5-triphosphate

LT Leukotriene

MAPK Mitogen-activated protein kinase

NF Nuclear factor

\section{References}

1. Gordon S, Taylor PR. Monocyte and macrophage heterogeneity. Nat Rev Immunol. 2005; 5:953-64. [PubMed: 16322748] 
2. Romagnani P, Annunziato F, Liotta F, Lazzeri E, Mazzinghi B, Frosali F, et al. CD14+CD34low cells with stem cell phenotypic and functional features are the major source of circulating endothelial progenitors. Circ Res. 2005; 97:314-22. [PubMed: 16020753]

3. Tacke F, Ginhoux F, Jakubzick C, van Rooijen N, Merad M, Randolph GJ. Immature monocytes acquire antigens from other cells in the bone marrow and present them to $\mathrm{T}$ cells after maturing in the periphery. J Exp Med. 2006; 203:583-97. [PubMed: 16492803]

4. Kanaoka Y, Boyce JA. Cysteinyl leukotrienes and their receptors: cellular distribution and function in immune and inflammatory responses. J Immunol. 2004; 173:1503-10. [PubMed: 15265876]

5. Peters-Golden M, Canetti C, Mancuso P, Coffey MJ. Leukotrienes: under-appreciated mediators of innate immune responses. J Immunol. 2005; 174:589-94. [PubMed: 15634873]

6. Lynch KR, O'Neill GP, Liu Q, Im DS, Sawyer N, Metters KM, et al. Characterization of the human cysteinyl leukotriene CysLT1 receptor. Nature. 1999; 399:789-93. [PubMed: 10391245]

7. Heise CE, O'Dowd BF, Figueroa DJ, Sawyer N, Nguyen T, Im DS, et al. Characterization of the human cysteinyl leukotriene 2 receptor. J Biol Chem. 2000; 275:30531-6. [PubMed: 10851239]

8. Ciana P, Fumagalli M, Trincavelli ML, Verderio C, Rosa P, Lecca D, et al. The orphan receptor GPR17 identified as a new dual uracil nucleotides/cysteinyl-leukotrienes receptor. EMBO J. 2006; 25:4615-27. [PubMed: 16990797]

9. Holgate ST, Peters-Golden M, Panettieri RA, Henderson WR Jr. Roles of cysteinyl leukotrienes in airway inflammation, smooth muscle function, and remodeling. J Allergy Clin Immunol. 2003; 111(suppl):S18-34. discussion S6. [PubMed: 12532084]

10. Fregonese L, Silvestri M, Sabatini F, Rossi GA. Cysteinyl leukotrienes induce human eosinophil locomotion and adhesion molecule expression via a CysLT1 receptor-mediated mechanism. Clin Exp Allergy. 2002; 32:745-50. [PubMed: 11994100]

11. Bautz F, Denzlinger C, Kanz L, Mohle R. Chemotaxis and transendothelial migration of CD34(+) hematopoietic progenitor cells induced by the inflammatory mediator leukotriene D4 are mediated by the 7-transmembrane receptor CysLT1. Blood. 2001; 97:3433-40. [PubMed: 11369634]

12. Thivierge M, Stankova J, Rola-Pleszczynski M. Toll-like receptor agonists differentially regulate cysteinyl-leukotriene receptor 1 expression and function in human dendritic cells. J Allergy Clin Immunol. 2006; 117:1155-62. [PubMed: 16675346]

13. Kim DC, Hsu FI, Barrett NA, Friend DS, Grenningloh R, Ho IC, et al. Cysteinyl leukotrienes regulate Th2 cell-dependent pulmonary inflammation. J Immunol. 2006; 176:4440-8. [PubMed: 16547282]

14. van de Ven R, de Jong MC, Reurs AW, Schoonderwoerd AJ, Jansen G, Hooijberg JH, et al. Dendritic cells require multidrug resistance protein 1 (ABCC1) transporter activity for differentiation. J Immunol. 2006; 176:5191-8. [PubMed: 16621983]

15. Robbiani DF, Finch RA, Jager D, Muller WA, Sartorelli AC, Randolph GJ. The leukotriene C(4) transporter MRP1 regulates CCL19 (MIP-3beta, ELC)-dependent mobilization of dendritic cells to lymph nodes. Cell. 2000; 103:757-68. [PubMed: 11114332]

16. Jahnsen FL, Moloney ED, Hogan T, Upham JW, Burke CM, Holt PG. Rapid dendritic cell recruitment to the bronchial mucosa of patients with atopic asthma in response to local allergen challenge. Thorax. 2001; 56:823-6. [PubMed: 11641504]

17. Parameswaran K, Liang H, Fanat A, Watson R, Snider DP, O’Byrne PM. Role for cysteinyl leukotrienes in allergen-induced change in circulating dendritic cell number in asthma. J Allergy Clin Immunol. 2004; 114:73-9. [PubMed: 15241347]

18. Thivierge M, Stankova J, Rola-Pleszczynski M. IL-13 and IL-4 up-regulate cysteinyl leukotriene 1 receptor expression in human monocytes and macrophages. J Immunol. 2001; 167:2855-60. [PubMed: 11509632]

19. Uzonyi B, Lotzer K, Jahn S, Kramer C, Hildner M, Bretschneider E, et al. Cysteinyl leukotriene 2 receptor and protease-activated receptor 1 activate strongly correlated early genes in human endothelial cells. Proc Natl Acad Sci U S A. 2006; 103:6326-31. [PubMed: 16606835]

20. Kharbanda S, Nakamura T, Stone R, Hass R, Bernstein S, Datta R, et al. Expression of the early growth response 1 and 2 zinc finger genes during induction of monocytic differentiation. J Clin Invest. 1991; 88:571-7. [PubMed: 1864967] 
21. Thompson C, Cloutier A, Bosse Y, Thivierge M, Gouill CL, Larivee P, et al. CysLT1 receptor engagement induces activator protein-1- and NF-kappaB-dependent IL-8 expression. Am J Respir Cell Mol Biol. 2006; 35:697-704. [PubMed: 16809637]

22. Wieland GD, Nehmann N, Muller D, Eibel H, Siebenlist U, Suhnel J, et al. Early growth response proteins EGR-4 and EGR-3 interact with immune inflammatory mediators NF-kappaB p50 and p65. J Cell Sci. 2005; 118:3203-12. [PubMed: 16014385]

23. Woszczek G, Pawliczak R, Qi HY, Nagineni S, Alsaaty S, Logun C, et al. Functional characterization of human cysteinyl leukotriene 1 receptor gene structure. J Immunol. 2005; 175:5152-9. [PubMed: 16210619]

24. Woszczek G, Chen LY, Nagineni S, Alsaaty S, Harry A, Logun C, et al. IFN- $\gamma$ induces cysteinyl leukotriene receptor 2 expression and enhances the responsiveness of human endothelial cells to cysteinyl leukotrienes. J Immunol. 2007; 178:5262-70. [PubMed: 17404310]

25. Kamakura S, Moriguchi T, Nishida E. Activation of the protein kinase ERK5/ BMK1 by receptor tyrosine kinases. J Biol Chem. 1999; 274:26563-71. [PubMed: 10473620]

26. Hoshino M, Izumi T, Shimizu T. Leukotriene D4 activates mitogen-activated protein kinase through a protein kinase Calpha-Raf-1-dependent pathway in human monocytic leukemia THP-1 cells. J Biol Chem. 1998; 273:4878-82. [PubMed: 9478929]

27. Capra V, Ravasi S, Accomazzo MR, Parenti M, Rovati GE. CysLT1 signal transduction in differentiated U937 cells involves the activation of the small GTP-binding protein Ras. Biochem Pharmacol. 2004; 67:1569-77. [PubMed: 15041474]

28. Mellor EA, Frank N, Soler D, Hodge MR, Lora JM, Austen KF, et al. Expression of the type 2 receptor for cysteinyl leukotrienes (CysLT2R) by human mast cells: functional distinction from CysLT1R. Proc Natl Acad Sci U S A. 2003; 100:11589-93. [PubMed: 13679572]

29. Hamilton A, Faiferman I, Stober P, Watson RM, O’Byrne PM. Pranlukast, a cysteinyl leukotriene receptor antagonist, attenuates allergen-induced early- and late-phase bronchoconstriction and airway hyperresponsiveness in asthmatic subjects. J Allergy Clin Immunol. 1998; 102:177-83. [PubMed: 9723658]

30. Leigh R, Vethanayagam D, Yoshida M, Watson RM, Rerecich T, Inman MD, et al. Effects of montelukast and budesonide on airway responses and airway inflammation in asthma. Am J Respir Crit Care Med. 2002; 166:1212-7. [PubMed: 12403690] 


\section{Clinical implications}

Antileukotriene therapies are likely to significantly block the proinflammatory functions of human monocytes. 


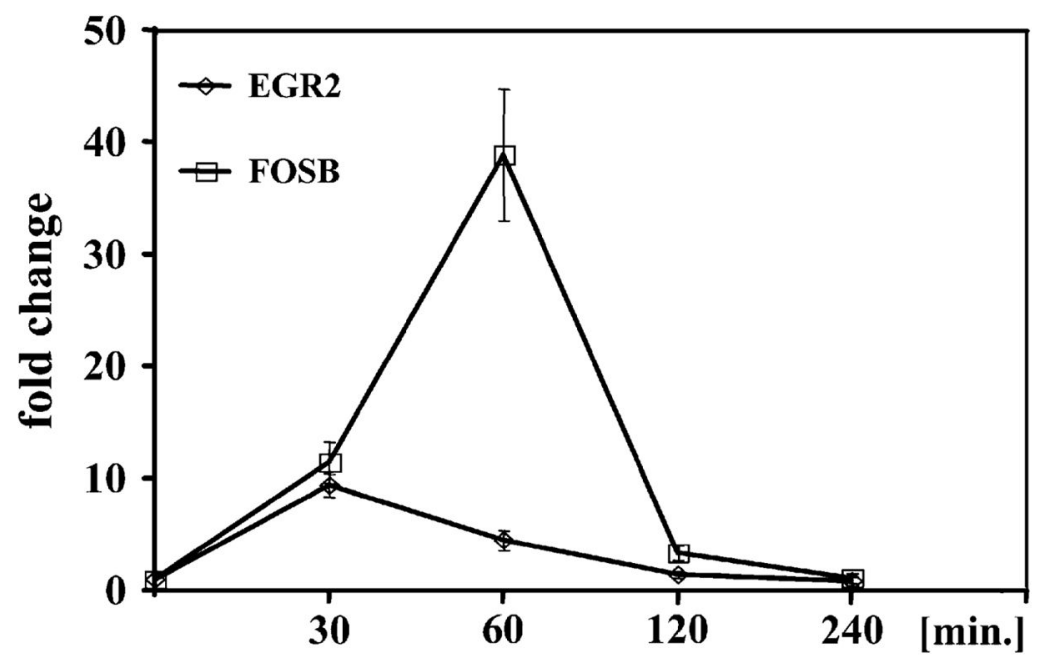

FIG 1.

$\mathrm{LTD}_{4}$ induces EGR2 and FOSB genes in a time-dependent fashion. Monocytes were stimulated with $\mathrm{LTD}_{4}(100 \mathrm{nmol} / \mathrm{L})$ for up to 4 hours, and mRNA expression was measured by means of TaqMan analysis. Data are presented as a fold change in comparison with vehicle (ethanol)-treated cells. Mean $\pm \mathrm{SD} ; \mathrm{n}=3$. 

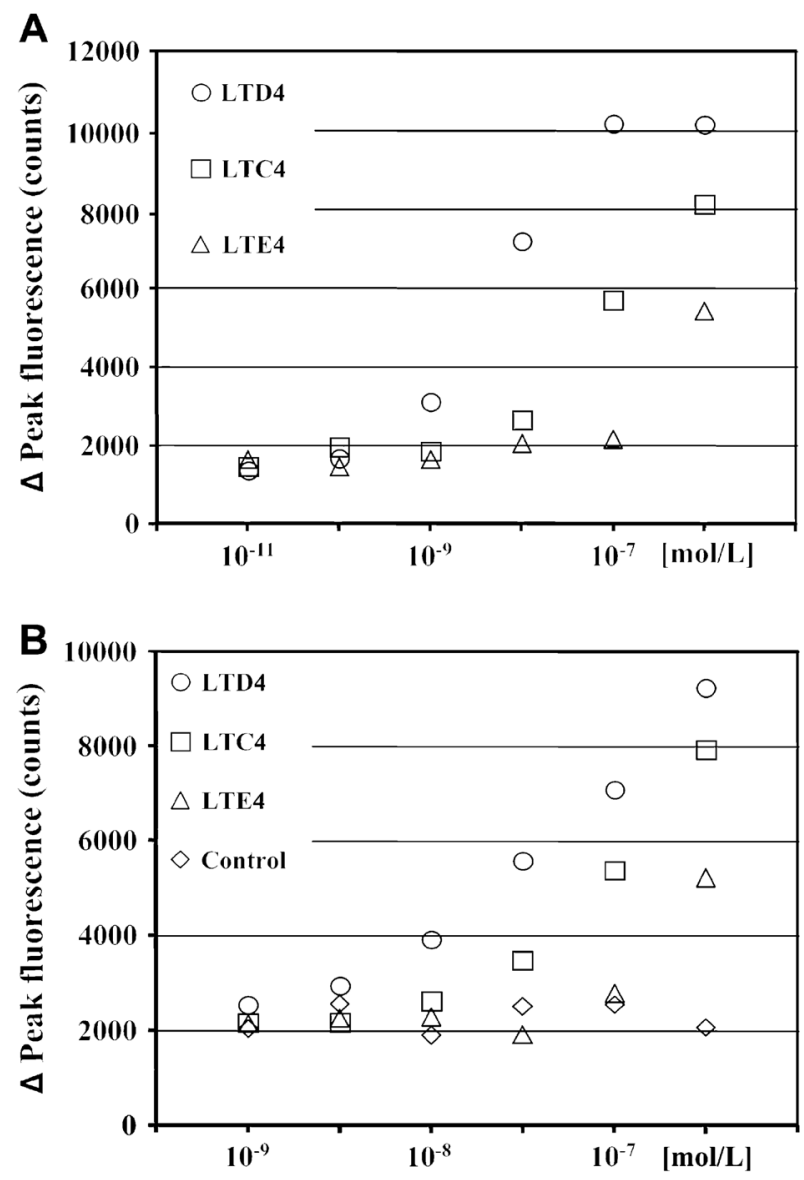

FIG 2.

Calcium mobilization responses to CysLTs. Monocytes (A) and CysLTR 1 -transfected HEK293 cells (B) were prepared and calcium release was measured as indicated in the Methods section. Data are presented as means from 2 separate experiments performed in triplicate. Empty pcDNA-transfected HEK293 cells treated with different concentrations of $\mathrm{LTD}_{4}$ were used as controls. 

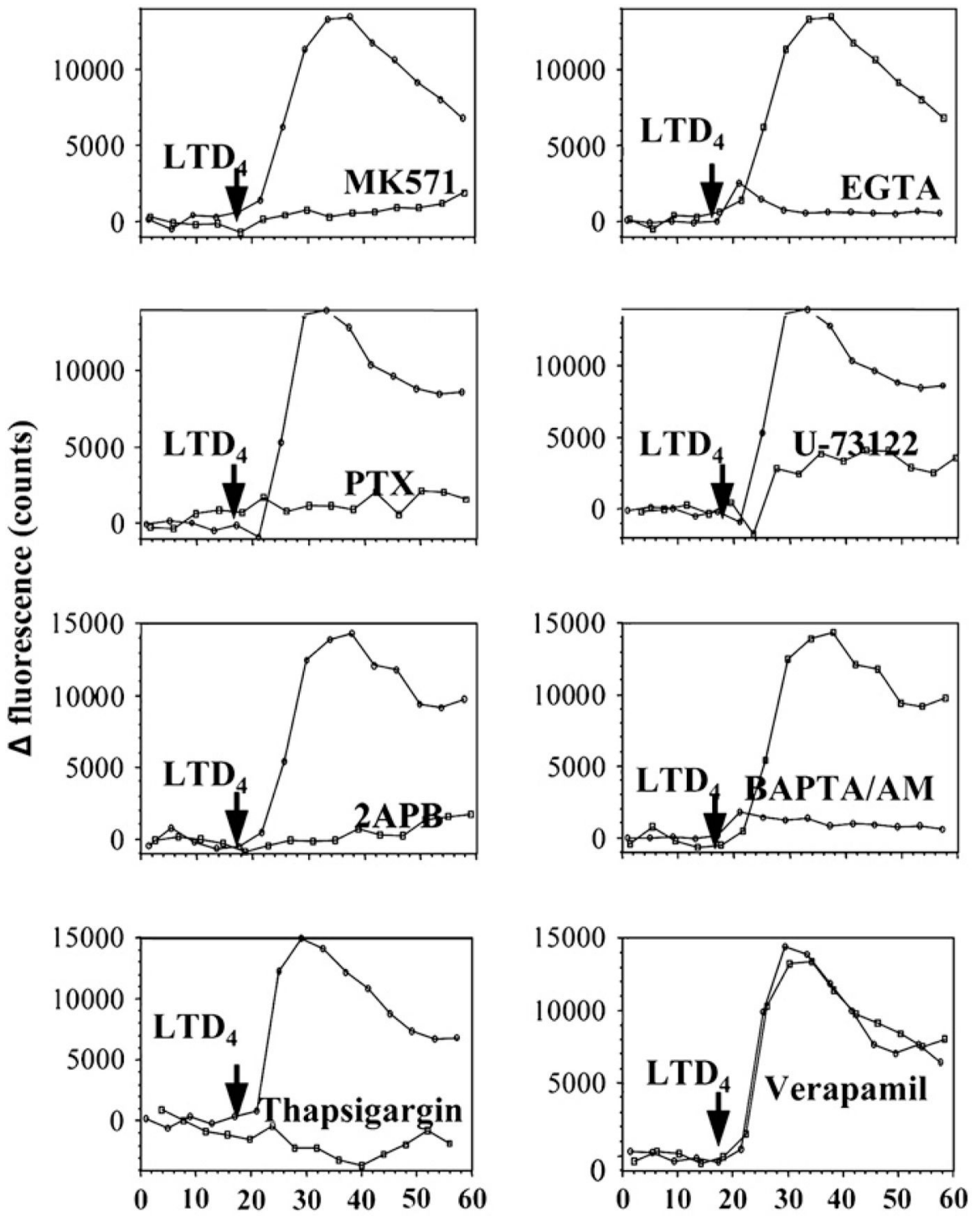

Time [sec.]

FIG 3.

Characterization of calcium mobilization responses to $\mathrm{LTD}_{4}$ in monocytes. Elutriated monocytes were prepared and calcium release was measured as indicated in the Methods section. Cells were preincubated with inhibitors or vehicle control as indicated in the Results section and stimulated with $\mathrm{LTD}_{4}(100 \mathrm{nmol} / \mathrm{L})$. Data from one of 3 experiments from 3 donors, each with similar results, are shown. 

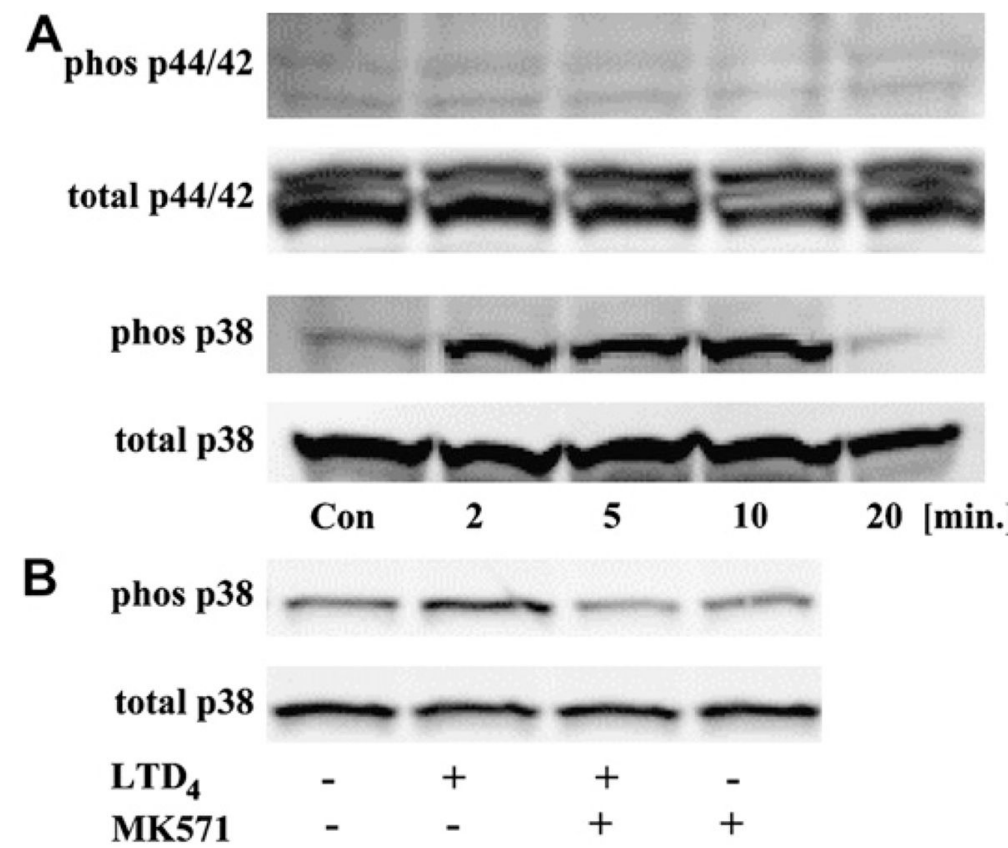

FIG 4.

The effect of $\mathrm{LTD}_{4}$ on MAPK activation. Monocytes were stimulated with $\mathrm{LTD}_{4}(100$ $\mathrm{nmol} / \mathrm{L}$ ) for different times, and phosphorylation of $\mathrm{p} 44 / 42$ and $\mathrm{p} 38$ was measured (A). Cells were preincubated with MK571 (100 nmol/L) for 10 minutes and stimulated with $\mathrm{LTD}_{4}(100$ $\mathrm{nmol} / \mathrm{L}$ ) for 10 minutes (B). Data are representative of 3 independent experiments. 

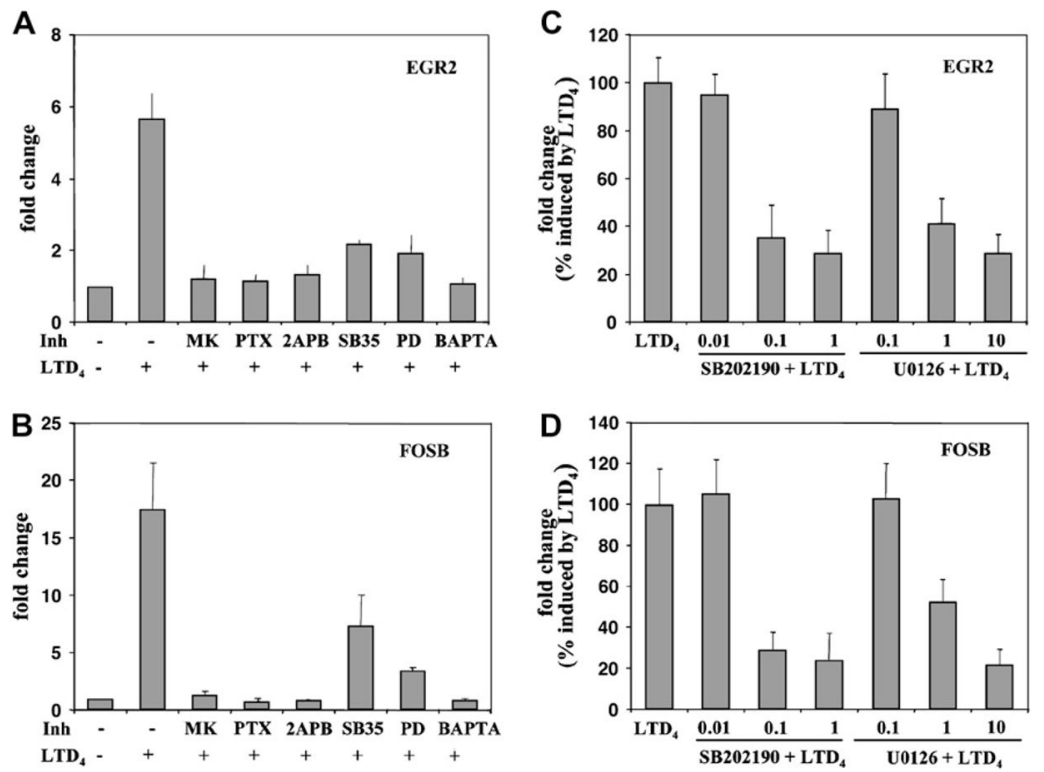

FIG 5.

Characterization of the pathway leading to $\mathrm{LTD}_{4}$-induced EGR2 and FOSB mRNA upregulation. Monocytes were preincubated with MK571 ( $M K ; 100 \mathrm{nmol} / \mathrm{L}$ for 10 minutes), pertussis toxin $(P T X ; 100 \mathrm{ng} / \mathrm{mL}$ overnight), 2APB (50 $\mu \mathrm{mol} / \mathrm{L}$ for 10 minutes), SB203580 (SB35; $5 \mu \mathrm{mol} / \mathrm{L}$ for 30 minutes), PD98059 ( $P D, 10 \mu \mathrm{mol} / \mathrm{L}$ for 30 minutes), BAPTA/AM (30 $\mu \mathrm{mol} / \mathrm{L}$ for 30 minutes) (A and $\mathbf{B}$ ) or with different concentrations of SB202190 (in micromoles per liter; 30 minutes) and U0126 (in micromoles per liter; 30 minutes) stimulated with $\mathrm{LTD}_{4}(100 \mathrm{nmol} / \mathrm{L})$ for 30 minutes $(\mathbf{C}$ and $\mathbf{D})$ and subjected to TaqMan analysis. Data are shown as a fold change in comparison with control vehicle-treated cells or expressed as the percentage of fold change induced by $\mathrm{LTD}_{4}$. Mean \pm SD; $n=6$ to 9. All inhibitors significantly inhibited $\mathrm{LTD}_{4}$-induced gene expression $(P<.001$ in comparison with $\mathrm{LTD}_{4}$ only-treated cells by using the Student $t$ test). 

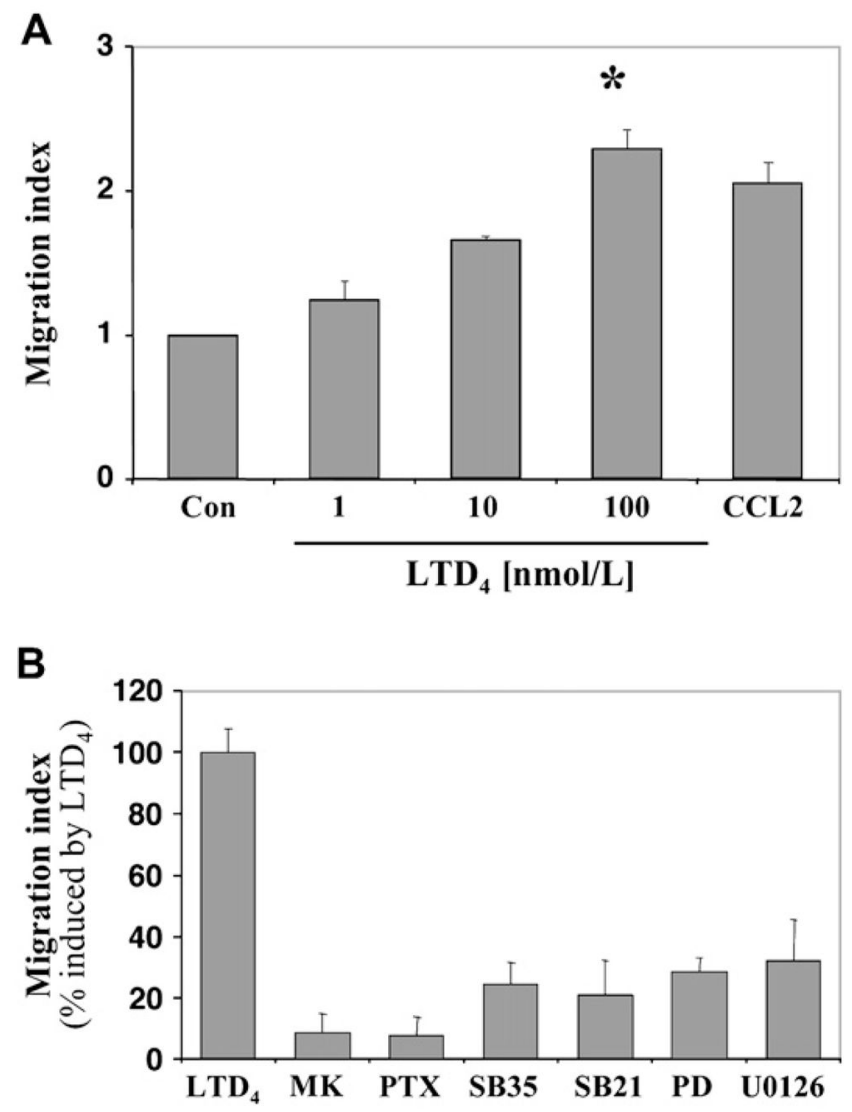

FIG 6.

Chemotactic responses of monocytes to $\mathrm{LTD}_{4}$. $\mathbf{A}$, Chemotactic activity of monocytes to different concentrations of $\mathrm{LTD}_{4}$ or CCL2 (5 nmol/L) as a positive control (Con) was measured as described in the Methods section. $\mathrm{LTD}_{4}$ induces chemotaxis of monocytes in a dose-dependent manner ( $* P<.001$, ANOVA). B, Cells were preincubated with MK571 ( $M K ; 100 \mathrm{nmol} / \mathrm{L}$ for 10 minutes), pertussis toxin (PTX; $100 \mathrm{ng} / \mathrm{mL}$ overnight), SB203580 (SB35; $5 \mu \mathrm{mol} / \mathrm{L}$ for 30 minutes), SB202190 (SB21; $1 \mu \mathrm{mol} / \mathrm{L}$ for 30 minutes), PD98059 $(P D ; 10 \mu \mathrm{mol} / \mathrm{L}$ for 30 minutes $)$, and $\mathrm{U} 0126$ (10 $\mu \mathrm{mol} / \mathrm{L}$ for 30 minutes $)$ and stimulated with $\mathrm{LTD}_{4}(100 \mathrm{nmol} / \mathrm{L})$. Data from 3 different donors are presented as the migration index in comparison with vehicle control or percentage of migration index induced by $\mathrm{LTD}_{4}(\mathrm{mean} \pm$ $\mathrm{SD})$. 


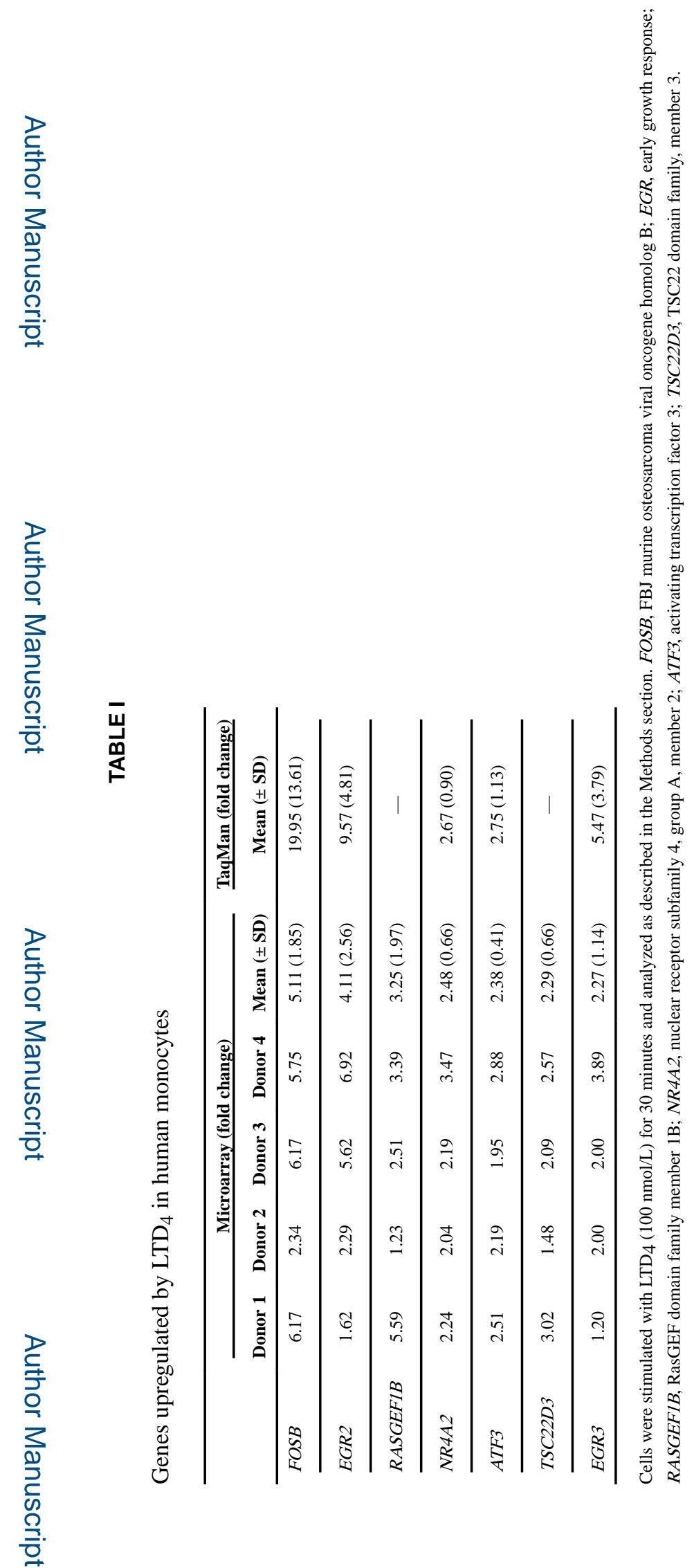

